\title{
Is morphology in Cercospora a reliable reflection of generic affinity?
}

\author{
MOUNES BAKHSHI ${ }^{1}$, MAHDI ARZANLOU ${ }^{1}$, ASADOLLAH BABAI-AHARI ${ }^{1}$, JOHANNES Z. GROENEWALD ${ }^{2}$ \\ \& PEDRO W. CROUS ${ }^{2,3,4}$ \\ ${ }^{1}$ Plant Protection Department, Faculty of Agriculture, University of Tabriz, P.O. Box 5166614766, Tabriz, Iran. \\ mounesbakhshi@gmail.com \\ ${ }^{2}$ CBS-KNAW Fungal Biodiversity Centre, Uppsalalaan 8, 3584 CT Utrecht, The Netherlands. \\ ${ }^{3}$ Department of Microbiology and Plant Pathology, Forestry and Agricultural Biotechnology Institute, University of Pretoria, Pretoria, \\ 0002 , South Africa. \\ ${ }^{4}$ Microbiology, Department of Biology, Utrecht University, Padualaan 8, 3584 CH Utrecht, The Netherlands.
}

\begin{abstract}
Cercospora (Mycosphaerellaceae) is a large genus of fungi comprising many important plant pathogens. In recent years DNA-based studies have revealed multiple genera of cercosporoid fungi being poly- and paraphyletic. Among these genera, the genus Cercospora has always been perceived as monophyletic. In the present study, phylogenetic inferences based on partial gene sequences of the LSU, ITS, ACT, TEF1- $\alpha$ and HIS loci, elucidated a cercospora-like taxon from Ammi majus to cluster in a clade apart from Cercospora s. str. In spite of numerous Cercospora spp. presently known from their DNA sequence data, this collection represents the first concrete evidence to the fact that the morphological characters previously attributed to Cercospora s. str. evolved more than once in the Mycosphaerellaceae. The genus Neocercospora is subsequently introduced to accommodate the Iranian taxon occurring on A. majus. Further collections on other hosts and from different continents are now required to establish the prevalence and relative importance of species of Neocercospora.
\end{abstract}

Key words: biodiversity, cercosporoid hyphomycetes, Mycosphaerellaceae, Neocercospora, phylogeny

\section{Introduction}

Cercosporoid fungi or Cercospora s. lat. belonging to Mycosphaerellaceae (Capnodiales), include numerous economically significant plant pathogens causing leaf spots on a wide variety of woody and herbaceous plants, but also can cause necrotic lesions on flowers, fruits, bracts, seeds and stems (Goodwin et al. 2001, Crous \& Braun 2003, Agrios 2005). They are found in different geographical and climatic zones across the world, and are especially abundant and diverse in tropical and subtropical areas (Braun et al. 2013, 2014). The frequent association of cercosporoid fungi with plant diseases has stimulated substantial interest in this group, and much of this attention has been focused on the systematics of species and genera in this complex (Deighton 1976, Pretorius et al. 2003, Braun \& Crous 2005, Crous et al. 2006, Arzanlou et al. 2008, Nakashima et al. 2011, Braun et al. 2013).

The first genus of cercosporoid hyphomycetes, Passalora, was introduced by Fries (1849), followed by Cercospora introduced by Fresenius (in Fuckel 1863). Since then, the taxonomy of this group has proven highly problematic. Chupp (1954) published the first monograph of cercosporoid hyphomycetes in which he followed a very broad generic concept and reduced many of the cercosporoid genera to synonymy with the genus Cercospora. Contrary to this approach, Deighton $(1967,1973,1976,1979,1987,1990)$ and Ellis $(1971,1976)$ in their treatments of cercosporoid fungi narrowed the generic concept of Cercospora s. lat. and divided it into smaller morphological units. Later, Crous \& Braun (2003) reviewed the genera of cercosporoid fungi and, due to numerous morphologically intermediate taxa and the first phylogenetic results based on DNA sequence data being available at the time (Crous et al. 2000), rearranged them into four genera viz. Cercospora, Passalora, Pseudocercospora and Stenella. These cercosporoid genera are mainly separated based on a combination of characters, of which the structure of the conidiogenous loci (scars) and hila, and the presence or absence of pigmentation in conidiophores and conidia are considered to be the most important (Crous \& Braun 2003).

With progress towards a stable phylogeny for the Mycosphaerellaceae (Arzanlou et al. 2007, Crous et al. 2007 , 
2009a, 2009b, Braun et al. 2013, Crous et al. 2013a, Groenewald et al. 2013), most of the assumptions made by Crous \& Braun (2003) regarding generic circumscriptions have been confirmed. However, several newly segregated cercosporoid genera have been also introduced, or old genera resurrected to reflect monophyletic, morphologically separated clades, e.g. Pallidocercospora, Paracercospora (Crous et al. 2013a), Phaeocercospora (Crous et al. 2012), Neopseudocercospora (Crous et al. 2013b) and Porocercospora (Amaradasa et al. 2014). In this regard, many cercosporoid genera have been revealed to represent polyphyletic taxa. Among these genera, the genus Cercospora which is recognised by having pigmented conidiophores with conspicuous (thickened and darkened) conidiogenous loci and hyaline conidia with conspicuous hila, has until now been supposed to be monophyletic (Groenewald et al. 2013, Bakhshi et al. 2015), at least as far as included phylogenetically-proven species are concerned. This monophyly is assumed based on the phylogenetic association of taxa to the type species of Cercospora, C. apii (see Crous \& Braun (2003), and Braun et al. (2013) for a discussion on the identity of the type species).

Members of cercosporoid fungi are known to be widely distributed, occurring on a broad range of plant hosts in many countries, including Iran. The biodiversity of cercosporoid fungi in Iran has recently received much attention (Bakhshi et al. 2014, 2015). Bakhshi et al. (2015) revised the taxonomy of the genus Cercospora in Iran by applying the Consolidated Species Concept (Quaedvlieg et al. 2014). These results indicated a rich diversity of Cercospora spp. in the north and north-west of Iran, including six novel species and several new host records (Bakhshi et al. 2015).

During the course of the present study, two isolates of cercosporoid fungi morphologically resembling species of the genus Cercospora were recovered from Bishop's flower (Ammi majus L.). A subsequent phylogenetic study based on different gene regions revealed these isolates to represent an undescribed genus. The aim of this study was thus to describe this novel cercospora-like genus and also elucidate the phylogenetic relationship of this genus to Cercospora and allied genera in Mycosphaerellaceae.

\section{Material and Methods}

\section{Isolates}

Symptomatic Bishop's flower (Ammi majus) leaves were collected in the field from Firouragh in the Khoy region, West Azerbaijan province, Iran, and taken to the laboratory. Leaves were examined directly under a Nikon SMZ 1500 stereo-microscope to observe sporulation. Single spore isolates derived from conidia, directly lifted from conidiophores on Bishop's flower leaves, were grown on 2\% malt extract agar (MEA; Fluka, Hamburg, Germany) using a previously described procedure (Bakhshi et al. 2011). Dried specimens are maintained in the Fungarium of the Iranian Research Institute of Plant Protection, Tehran, Iran (IRAN). Representative cultures were deposited in the Culture Collection of Tabriz University (CCTU) and the Centraalbureau voor Schimmelcultures (CBS-KNAW Fungal Biodiversity Centre, Utrecht, The Netherlands).

\section{DNA extraction, amplification and sequencing}

Fungal isolates were grown on MEA for $10 \mathrm{~d}$ at $25^{\circ} \mathrm{C}$ in the dark. The mycelia were harvested with a sterile scalpel and genomic DNA isolated using the protocol of Möller et al. (1992). DNA samples were diluted 50-100 times in preparation for further DNA amplification reactions. Parts of the following loci were amplified and sequenced: $28 \mathrm{~S}$ nrRNA gene (LSU) with the primer pairs LROR (Rehner \& Samuels 1994) and LR5 (Vilgalys \& Hester 1990), the internal transcribed spacer regions and intervening 5.8S nrRNA gene (ITS) of the nrDNA operon with the primer pairs V9G (de Hoog \& Gerrits van den Ende 1998) and ITS4 (White et al. 1990), a fragment of the actin gene (ACT) with the primer set ACT-512F and ACT-783R (Carbone \& Kohn 1999), part of the translation elongation factor 1-alpha (TEF1- $\alpha$ ) using the primer set EF1-728F (Carbone \& Kohn 1999) and EF-2 (O'Donnell et al. 1998) and a fragment of the histone $\mathrm{H} 3$ gene (HIS) with the primer set CylH3F and CylH3R (Crous et al. 2004b). All PCR reaction mixtures and conditions were performed in a total volume of $12.5 \mu \mathrm{l}$ as described by Bakhshi et al. (2015).

Both strands of the PCR fragments were sequenced with the BigDye ${ }^{\circledR}$ Terminator Cycle Sequencing reaction Kit v. 3.1 (Applied Biosystems ${ }^{\mathrm{TM}}$, Foster City, CA, USA), following the manufacturer's instructions, using the same primer pairs used for amplification. Sequencing amplicons were purified through Sephadex G-50 Superfine columns (Sigma Aldrich, St. Louis, MO) in a 96-well MultiScreen HV plate (Millipore, Billerica, MA) and analysed with an ABI Prism 3730xl DNA Analyzer (Life Technologies Europe BV, Applied Biosystems ${ }^{\mathrm{TM}}$, Bleiswijk, The Netherlands) according to manufacturer's recommendation. 
TABLE 1 A list of isolates and their GenBank accessions used in phylogenetic analyses. Bold accession numbers were generated in this study.

\begin{tabular}{|c|c|c|c|c|c|}
\hline \multirow[t]{2}{*}{ Species } & \multirow[t]{2}{*}{ Culture accession number $(\mathrm{s})^{1}$} & \multicolumn{4}{|c|}{ GenBank accession numbers } \\
\hline & & ITS & TEF $1-\alpha$ & ACT & HIS \\
\hline Caryophylloseptoria lychnidis & CBS 109102 & KF251289 & KF253237 & KF253598 & - \\
\hline Caryophylloseptoria silenes & CBS 109103 & KF251293 & KF253241 & KF253602 & - \\
\hline Cercospora althaeina & CBS 248.67; CPC 5117 & JX143530 & JX143284 & JX143038 & JX142546 \\
\hline Cercospora apii & CBS 114418; CPC 10924 & AY840517 & AY840484 & AY840448 & AY840382 \\
\hline Cercospora apii & CBS 116455; CPC 11556 & AY840519 & AY840486 & AY840450 & AY840384 \\
\hline Cercospora apii & CBS 553.71; IMI 161116; CPC 5083 & DQ233320 & DQ233344 & DQ233370 & DQ233422 \\
\hline Cercospora armoraciae & CBS 136132; CCTU 1117 & KJ886418 & KJ886257 & KJ885935 & KJ886096 \\
\hline Cercospora armoraciae & CBS 136134; CCTU 1190 & KJ886422 & KJ886261 & KJ885939 & KJ886100 \\
\hline Cercospora armoraciae & CBS 250.67; CPC 5088 & JX143545 & JX143299 & JX143053 & JX142561 \\
\hline Cercospora beticola & CBS 124.31; CPC 5070 & AY840523 & AY840490 & AY840454 & AY840388 \\
\hline Cercospora beticola & CBS 116456; CPC 11557 & AY840527 & AY840494 & AY840458 & AY840392 \\
\hline Cercospora campi-silii & CBS 132625; CPC 14585 & JX143561 & JX143315 & JX143069 & JX142577 \\
\hline Cercospora canescens complex & CBS 111133; CPC 1137 & AY260065 & DQ835084 & DQ835103 & DQ835157 \\
\hline Cercospora capsici & CBS 118712 & GU214653 & JX143322 & JX143076 & JX142584 \\
\hline Cercospora celosiae & CBS 132600; CPC 10660 & JX143570 & JX143326 & JX143080 & JX142588 \\
\hline Cercospora conyzae-canadensis & CBS 135978; CCTU 1119 & KJ886445 & KJ886284 & KJ885962 & KJ886123 \\
\hline Cercospora cylindracea & CCTU 1114 & KJ886450 & KJ886289 & KJ885967 & KJ886128 \\
\hline Cercospora cylindracea & CCTU 1189 & KJ886452 & KJ886291 & KJ885969 & KJ886130 \\
\hline Cercospora pseudochenopodii & CCTU 1176 & KJ886518 & KJ886357 & KJ886035 & KJ886196 \\
\hline Cercospora senecionis-walkeri & CBS 132636; CPC 19196 & JX143649 & JX143408 & JX143162 & JX142670 \\
\hline Cercospora sojina & CBS 132018; CPC 12322 & GU214655 & JX143418 & JX143172 & - \\
\hline Cercospora sorghicola & CBS 136448; CCTU 1173 & KJ886525 & KJ886364 & KJ886042 & KJ886203 \\
\hline Cercospora sp. G & CBS 136023; CCTU 1020 & KJ886529 & KJ886368 & KJ886046 & KJ886207 \\
\hline Cercospora sp. G & CCTU 1116 & KJ886537 & KJ886376 & KJ886054 & KJ886215 \\
\hline Cercospora violae & CBS 251.67; CPC 5079 & JX143737 & JX143496 & JX143250 & JX142758 \\
\hline Cercospora zeae-maydis & CBS 117757 & DQ185074 & DQ185086 & DQ185098 & DQ185122 \\
\hline Cercospora zeae-maydis & CBS 132678; CPC 15602 & JX143743 & JX143502 & JX143256 & JX142764 \\
\hline Cercospora zebrina & CCTU 1110 & KJ886546 & KJ886385 & KJ886063 & KJ886224 \\
\hline Cercospora zebrina & CBS 118790 & JX143748 & JX143510 & JX143264 & JX142772 \\
\hline Cercospora zeina & CBS 118820; CPC 11995 & DQ185081 & DQ185093 & DQ185105 & DQ185129 \\
\hline Cladosporium herbarum & CBS 121621 & EF679363 & EF679440 & EF679516 & EF679670 \\
\hline Neocercospora ammicola & CBS 136450; CCTU 1186 & KR232407 & KR232409 & KR232411 & KR232413 \\
\hline Neocercospora ammicola & CCTU 1187 & KR232408 & KR232410 & KR232412 & KR232414 \\
\hline Passalora eucalypti & CBS 111318 & GU269845 & GU384558 & GU320548 & - \\
\hline Phloeospora ulmi & CBS 344.97 & JQ324974 & JQ324986 & GU320528 & - \\
\hline Phloeospora ulmi & CBS 613.81 & GU269825 & JQ324987 & GU320529 & - \\
\hline Pseudocercospora abelmoschi & CPC 14478; CBS 132103 & GU269647 & GU384365 & GU320355 & - \\
\hline Pseudocercospora eucalyptorum & CPC 12568; CBS 132309 & GU269796 & GU384506 & GU320497 & - \\
\hline Pseudocercospora humulicola & CPC 11358; CBS 131585 & GU269723 & GU384438 & GU320427 & - \\
\hline Pseudocercospora norchiensis & CBS 114641 & GU269772 & GU384484 & GU320475 & - \\
\hline Pseudocercospora vitis & CPC 11595; CBS 132012 & GU269829 & GU384541 & GU320533 & - \\
\hline Pseudocercosporella arcuata & CPC 10050 & GU269850 & JQ325006 & GU320554 & - \\
\hline Pseudocercosporella capsellae & CBS 112033 & KF251306 & KF253254 & KF253615 & - \\
\hline Pseudocercosporella capsellae & CBS 127.29 & KF251326 & KF253273 & KF253632 & - \\
\hline Pseudocercosporella oxalidis & CBS 118758 & GU269756 & GU384467 & GU320458 & - \\
\hline
\end{tabular}

1 CBS: CBS-KNAW Fungal Biodiversity Centre, Utrecht, The Netherlands; CPC: Culture collection of Pedro Crous, housed at CBS; CCTU:

Culture Collection of Tabriz University, Tabriz, Iran; IMI: International Mycological Institute, CABI-Bioscience, Egham, Bakeham Lane, U.K.

\section{Phylogenetic analyses}

The DNA sequences generated with forward and reverse primers were edited using MEGAv. 6 (Tamura et al. 2013) and a consensus sequence was generated manually for each set of forward and reverse sequences. Megablast searches of the NCBI's GenBank nucleotide database were used to supplement the sequence data obtained in this study. Sequences were aligned with the MAFFT online interface using default settings (http://mafft. cbrc.jp/alignment/server/) (Katoh 
\& Standley 2013). The alignments were manually checked and improved where necessary using MEGA v. 6 and were concatenated with Mesquite v. 2.75 (Maddison \& Maddison 2011).

A Markov Chain Monte Carlo (MCMC) algorithm was used to generate Bayesian Inference (BI) phylogenetic trees with Bayesian probabilities using MrBayes v. 3.2.2 (Ronquist et al. 2012). Models of nucleotide substitution were selected independently for each locus under the Akaike Information Criterion (AIC) using MrModeltest v. 2.3 (Nylander 2004). The analyses of two parallel MCMC algorithms, each consisting of four chains, were run from random trees for 100000000 generations until the average standard deviation of split frequencies reached a value of 0.01 , with trees saved every 1000 generations and the heating parameter was set to 0.15 . The first $25 \%$ of saved trees were discarded as the 'burn-in' phase and the posterior probabilities (Rannala \& Yang 1996) were calculated from the remaining trees. The resulting phylogenetic tree was printed with Geneious v. 5.6.7 (Drummond et al. 2012). All new sequences generated during this study were deposited in NCBIs GenBank nucleotide database (www.ncbi.nlm. nih.gov) and the accession numbers of the sequences used for the phylogenetic analyses are listed in Table 1. The alignment and phylogenetic trees were deposited in TreeBASE (www.TreeBASE.org).

\section{Morphology}

Morphological characterisations were based on both structures from herbarium material (in planta) and structures from culture (in vitro). For in planta descriptions, diseased leaf tissues were observed under a stereo-microscope and relevant morphological structures (stromata, conidiophores and conidia) were picked up from lesions with a sterile inoculation needle and mounted on glass slides in clear lactic acid. For in vitro descriptions, cultures were plated on fresh MEA and subsequently incubated at $20^{\circ} \mathrm{C}$ under continuous near-ultraviolet light, and examined after 2-4 weeks for sporulation. Observations were made at $\times 1000$ magnification for microscopic structures using a Nikon Eclipse 80i light microscope, and $95 \%$ confidence intervals were derived for the 30 measurements with extreme values given in parentheses. High-resolution photographs of microscopic fungal structures mounted in clear lactic acid were captured with a Nikon digital sight DS-f1 high definition colour camera mounted on the Nikon Eclipse 80i light microscope. Adobe Photoshop CS3 was used for the final editing of acquired images and photographic preparations.

Colony macro-morphology was assessed on MEA at $25^{\circ} \mathrm{C}$ in the dark in triplicate. After 20 days, the colony diameter was measured and the colony colour was assessed according to the mycological colour charts of Rayner (1970). Descriptions, nomenclature and illustrations were deposited in MycoBank (www.MycoBank.org; Crous et al. 2004a).

\section{Results}

\section{DNA sequencing and phylogenetic analyses}

For two cercospora-like strains obtained from Ammi majus in this study, amplification of the five loci (LSU, ITS, ACT, TEF1- $\alpha$, HIS), yielded fragments of approximately 900, 700, 200, 300 and $400 \mathrm{bp}$, respectively. Two BI phylogenetic analyses were performed: 1) an initial analysis of the LSU region to determine the generic position of the obtained isolates in the Mycosphaerellaceae; 2) a combined analysis of the ITS, ACT, TEF1- $\alpha$ and HIS to fully resolve the phylogenetic relation of the isolates in this study with the different species of the Cercospora s. str. clade (Groenewald et al. 2013, Bakhshi et al. 2015).

\section{LSU dataset}

During phylogenetic analyses, the obtained LSU sequences in this study were aligned with LSU sequence data of 33 Mycosphaerellaceae taxa in order to establish how these isolates are related to other well-established genera within Mycosphaerellaceae. The final aligned LSU dataset contained 35 ingroup taxa with a total of 735 characters, containing 114 unique site patterns and Cladosporium herbarum (GenBank accession DQ678074) served as the outgroup taxon. The results of MrModeltest recommended a general time reversible (GTR) substitution model with inverse gamma rates and dirichlet base frequencies. During the generation of the tree, a total of 512 trees were saved, and the 50\% majority rule consensus tree (Fig. 1) and posterior probabilities (PP) were calculated from the remaining 384 (75\%) trees. The phylogenetic analysis of the Mycosphaerellaceae LSU dataset showed isolates from Ammi majus clustering in a distinct monophyletic clade that is sister to the Phloeospora, Ramulispora and Pseudocercosporella capsellae clades (Fig. 1). 


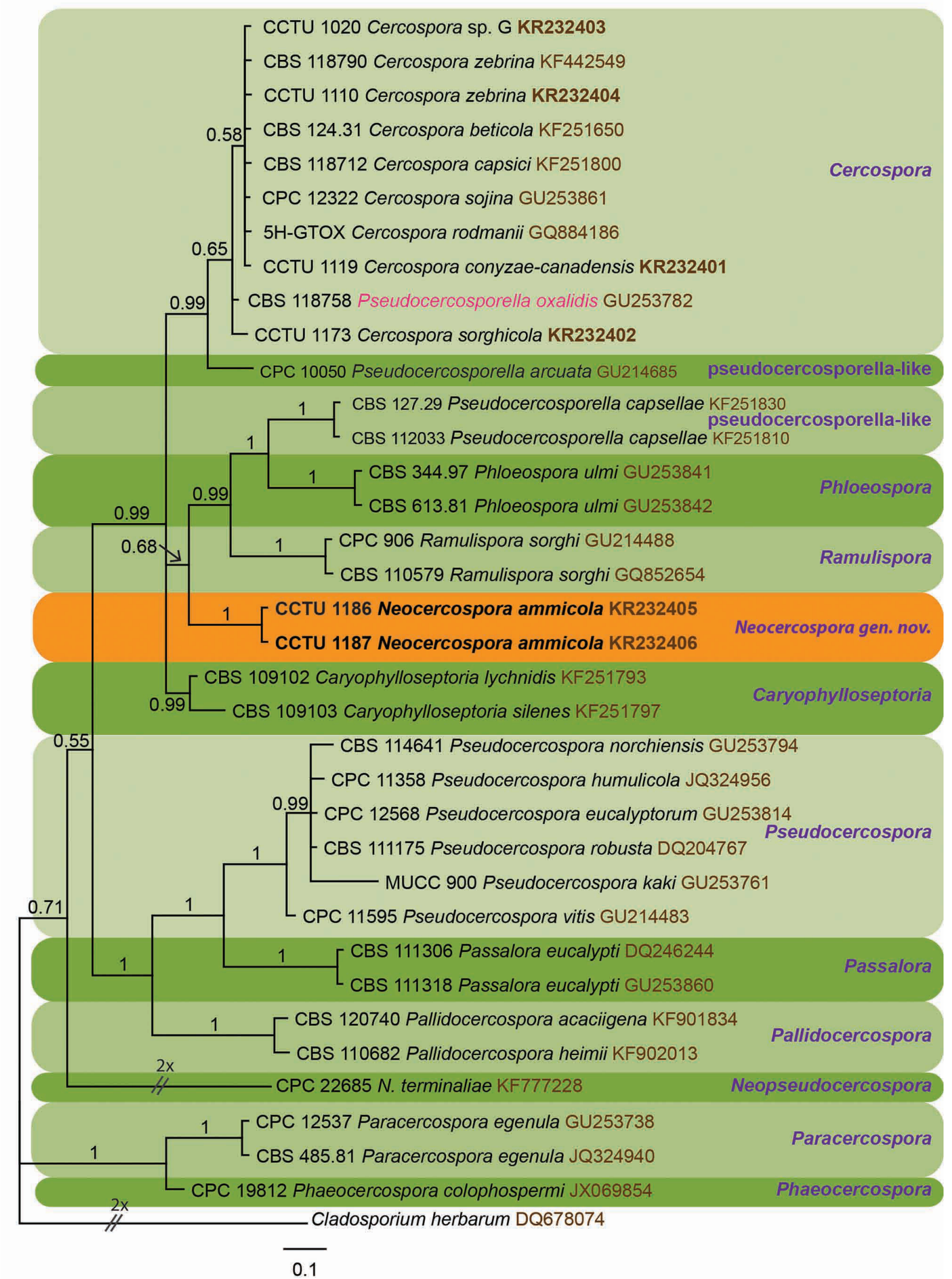

FIGURE 1. Consensus phylogram (50\% majority rule) of 512 trees resulting from a Bayesian analysis of the LSU sequence alignment using MrBayes v. 3.2.2. The scale bar represents the average number of substitutions per site, and posterior probability values are shown at the nodes. GenBank accession numbers are shown in brown text and bold accession numbers were generated in this study. Clades of different genera are indicated in coloured blocks and names of the genera are shown in purple text. The tree is rooted to Cladosporium herbarum (GenBank accession DQ678074). 


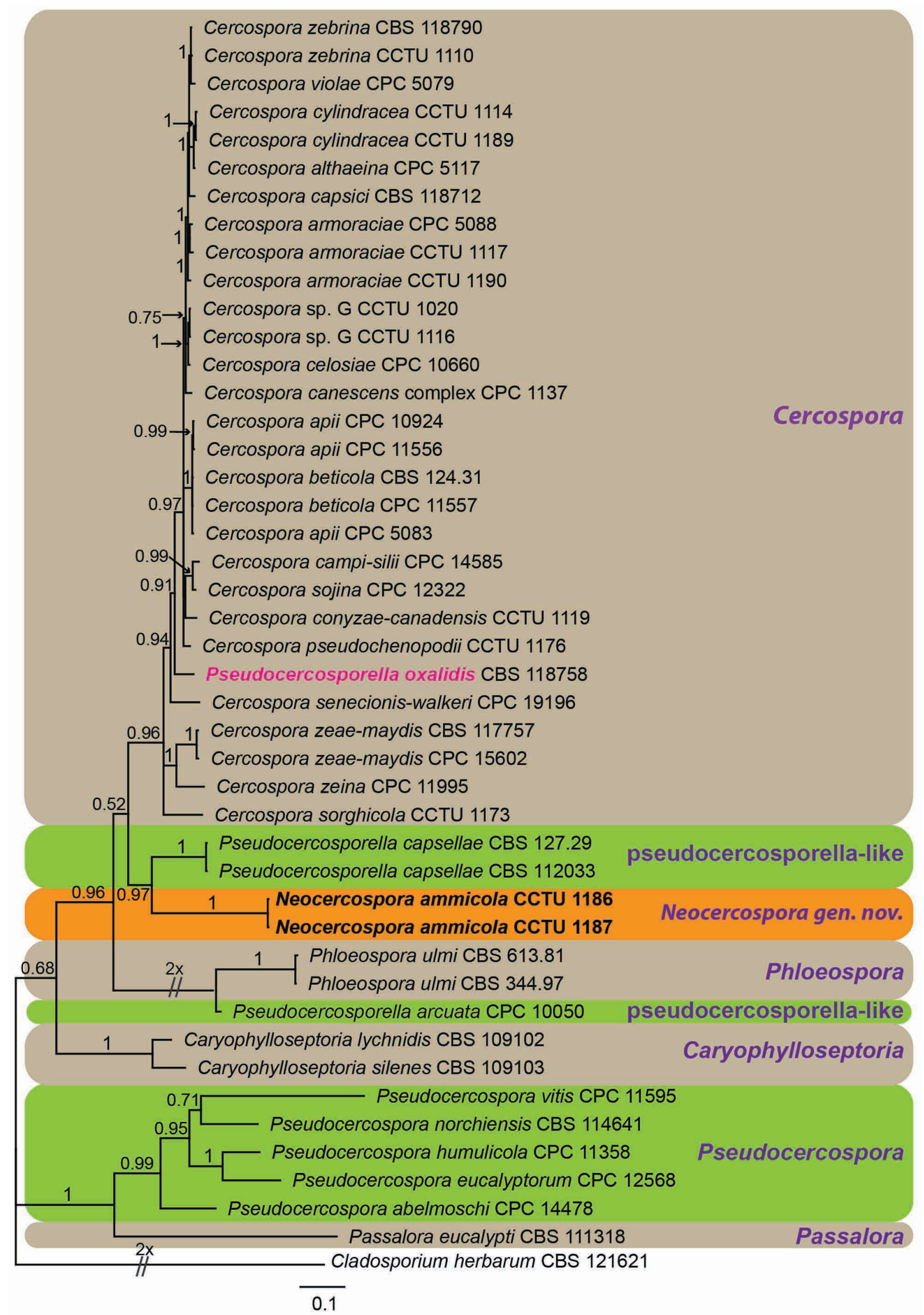

FIGURE 2. Consensus phylogram (50\% majority rule) of 622 trees resulting from a Bayesian analysis of the combined 4-gene (ITS, TEF1- $\alpha$, ACT and HIS) sequence alignment using MrBayes v. 3.2.2. The scale bar represents the average number of substitutions per site, and posterior probability values are shown at the nodes. Clades of different genera are indicated in coloured blocks and names of the genera are shown to the right of the block. The tree is rooted to Cladosporium herbarum (strain CBS 121621). 


\section{Multi-locus dataset}

The combined ITS/TEF1- $\alpha / \mathrm{ACT} / \mathrm{HIS}$ alignment contained 45 taxa including Cladosporium herbarum (isolate CBS 121621) as outgroup taxon, and 1659 characters including alignment gaps were used. The gene regions in the alignment were 1-514 for ITS, 519-1092 for TEF1- $\alpha, 1097-1293$ for ACT and 1298-1655 for HIS. The alignment contained a total of 720 unique site patterns: 155 (ITS), 357 (TEF1- $\alpha$ ), 122 (ACT), 86 (HIS). The results of the MrModeltest analyses recommended a $\mathrm{HKY}+\mathrm{I}+\mathrm{G}$ for TEF $1-\alpha$ and $\mathrm{HIS}$, while a $\mathrm{GTR}+\mathrm{G}$ for ITS and ACT. All partitions had dirichlet base frequencies. The Bayesian analysis generated 622 trees from which 154 trees were discarded ( $25 \%$ burn in). The $50 \%$ majority rule consensus tree (Fig. 2) and posterior probabilities were calculated from the remaining 468 trees. Based on the results of combined gene tree, the isolates from Ammi majus cluster in a distinct well-supported clade sister to the clade including Pseudocercosporella capsellae strains (Fig. 2).

\section{Taxonomy}

Based on the LSU (Fig. 1) and multi-locus (Fig. 2) DNA datasets, cercospora-like isolates occurring on Ammi majus clustered in a separate clade, distinct from Cercospora s. str., suggesting that they represented a distinct genus in the Mycosphaerellaceae. Due to their distinct phylogenetic placement, a new genus, Neocercospora, is hereby introduced for the isolates occurring on Ammi majus.

\section{Neocercospora M. Bakhshi, Arzanlou, Babai-ahari \& Crous, gen. nov. MycoBank MB 812284}

Foliicolous and caulicolous, phytopathogenic. Mycelium internal. Stromata substomatal, weakly to moderately developed, brown. Caespituli amphigenous, punctiform, brown. Conidiophores aggregated in loose to moderately dense fascicles, arising from the upper cells of substomatal to intraepidermal brown stromata; conidiophores aseptate, reduced to conidiogenous cells. Conidiogenous cells unbranched, pale brown to brown, smooth, subcylindrical to cone-shaped, wider at the base, unito multilocal, sympodial, subdenticulate; loci conspicuous, thickened, darkened, somewhat refractive, apical or formed on shoulders caused by geniculation. Conidia solitary or catenate, in unbranched chains, hyaline, smooth, guttulate or not, cylindrical, subcylindrical to obclavate-cylindrical, straight to slightly curved, septate; hilum flattened, moderately thickened, darkened and somewhat refractive.

Type species:-Neocercospora ammicola M. Bakhshi, Arzanlou, Babai-ahari \& Crous.

Etymology:-New genus resembling Cercospora in morphology.

Neocercospora ammicola M. Bakhshi, Arzanlou, Babai-ahari \& Crous, sp. nov. (Fig. 3, 4.) MycoBank MB 812288

Type:-IRAN. West Azerbaijan Province: Khoy, Firouragh, on leaves and stems of Ammi majus L. (Apiaceae), Sept. 2012, M. Arzanlou (holotype IRAN 16461 F, culture ex-type CCTU 1186 = CBS 136450).

Description in planta:-Foliicolous and caulicolous, phytopathogenic. Leaf spots amphigenous, circular to subcircular, 1-4 mm diam., brown, with raised, dark brown border. Mycelium internal. Stromata substomatal, weakly to moderately developed, brown, 5-18 $\mu \mathrm{m}$ diam. Caespituli amphigenous, punctiform, brown. Conidiophores aggregated in loose to moderately dense fascicles (1-12), arising from the upper cells of substomatal to intraepidermal brown stromata, up to $18 \mu \mathrm{m}$ wide and $27 \mu \mathrm{m}$ high, emerging through stomata or erumpent; conidiophores aseptate, reduced to conidiogenous cells. Conidiogenous cells unbranched, pale brown to brown, smooth, subcylindrical to cone-shaped, wider at the base, gradually becoming narrower towards the apex, occasionally geniculate-sinuous, $(10-) 14.5-17(-25) \times 2.5-3.5(-4)$ $\mu \mathrm{m}$, unilocal and multilocal, sympodial, subdenticulate; loci, conspicuous, thickened, darkened, somewhat refractive, apical or formed on shoulders caused by geniculation, 1-2.5 $\mu \mathrm{m}$ diam. Conidia solitary or catenate, in unbranched chains, hyaline, smooth, guttulate or not, cylindrical, subcylindrical to obclavate-cylindrical, straight to slightly curved, 1-10-septate, $(15-) 35-50(-110) \times(2.5-) 3-3.5(-4) \mu \mathrm{m}$, apex obtuse, base obconically truncate or truncate with slight basal taper to hilum, 1-2 $\mu \mathrm{m}$ diam., flattened, moderately thickened, darkened and somewhat refractive.

Description in vitro on MEA:-Mycelia consisting of hyaline, branched, septate, smooth hyphae, 2-6 $\mu \mathrm{m}$ diam, guttulate, gradually becoming pale to medium brown and somewhat verruculose at fertile regions. Conidiophores solitary or in loose fascicles, unbranched, pale brown, becoming darker towards the apex, semi-macronematous to 
macronematous, up to $85 \mu \mathrm{m}$ tall, (3-)3.5-4(-5) $\mu \mathrm{m}$ wide, 0-6-septate, septa 10-20 $\mu \mathrm{m}$ apart (but not observed in planta), often reduced to solitary conidiogenous cells. Conidiogenous cells integrated, terminal or lateral or terminal on hyphae when 1-celled, medium brown to brown, (15-)20-25(-35) × 3-3.5(-4.5) $\mu \mathrm{m}$, uni- and multilocal, sympodial, subdenticulate; loci moderately conspicuous, slightly thickened and darkened, somewhat refractive, apical or formed on shoulders caused by geniculation, 1-2.5 $\mu \mathrm{m}$ diam. Conidia solitary or catenate, in unbranched chains, hyaline, smooth, guttulate or not, cylindrical to subcylindrical, straight to gently curved, indistinctly 1-9-septate, (25-)45$60(-95) \times(2-) 2.5-3(-4) \mu \mathrm{m}$; apex obtuse or subobtuse, base obconically truncate or truncate with slight basal taper to hilum; hila flattened, with marginal thickening along the rim, somewhat refractive, 1-2 $\mu \mathrm{m}$ diam.

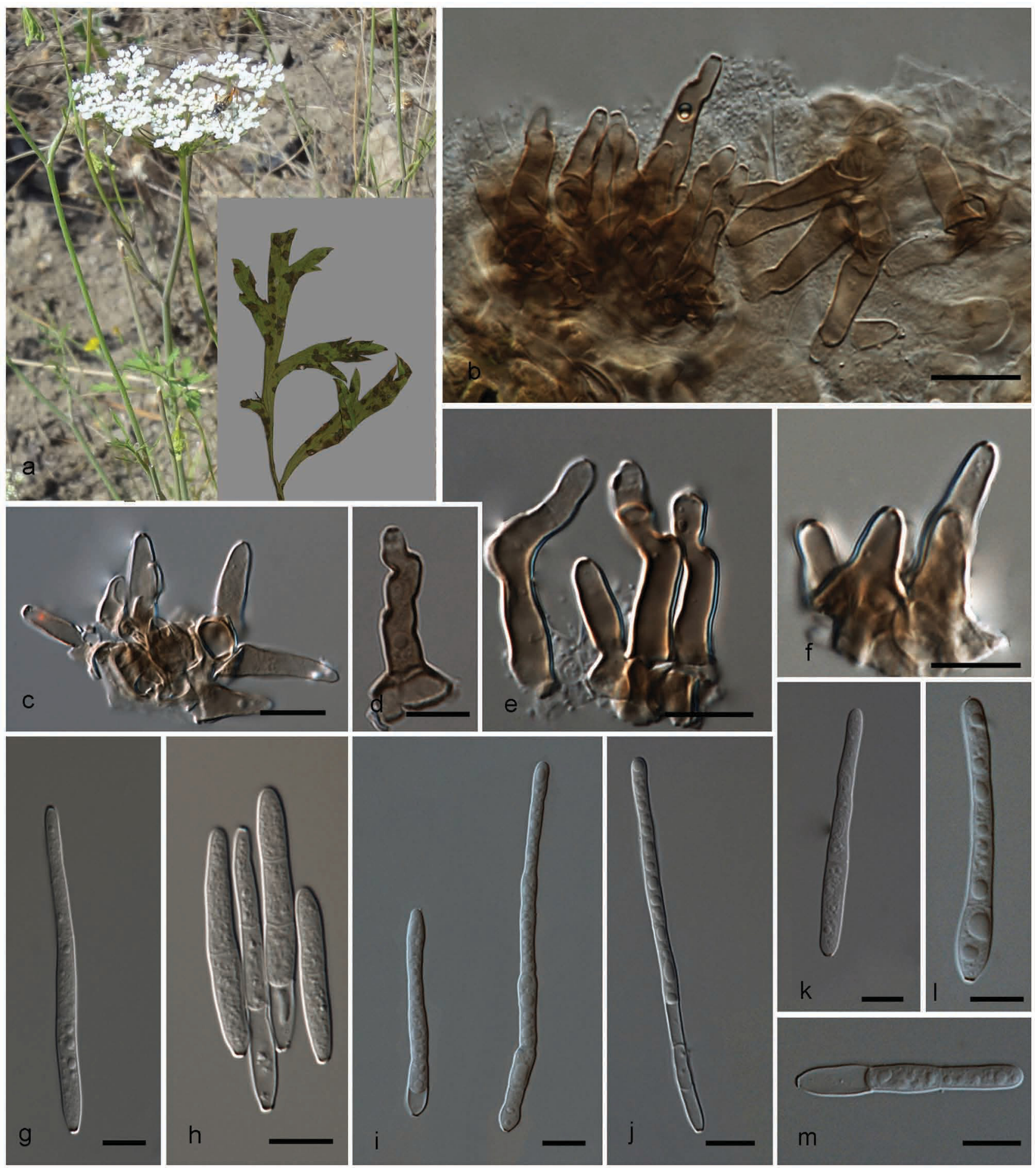

FIGURE 3. Neocercospora ammicola (CBS 136450) (in vivo). a. Leaf spots on Ammi majus. b-f. Fasciculate conidiophores reduced to conidiogenous cells. g-m. Solitary and catenate conidia. Scale bars $=10 \mu \mathrm{m}$. 
Cultural characteristics:-Colonies on MEA after 20 days at $25^{\circ} \mathrm{C}$ in the dark up to $35 \mathrm{~mm}$ diam., erumpent with smooth, uneven margins and moderate aerial mycelium; surface olivaceous black, reverse iron-grey.

Habitat/Distribution:-Known to inhabit Ammi majus, West Azerbaijan Province, Iran.

Etymology:-Named after the host genus from which it was isolated, Ammi.

Other material examined:--IRAN. West Azerbaijan Province: Khoy, Firouragh, on Ammi majus, Sept. 2012, M. Arzanlou (CCTU 1187).
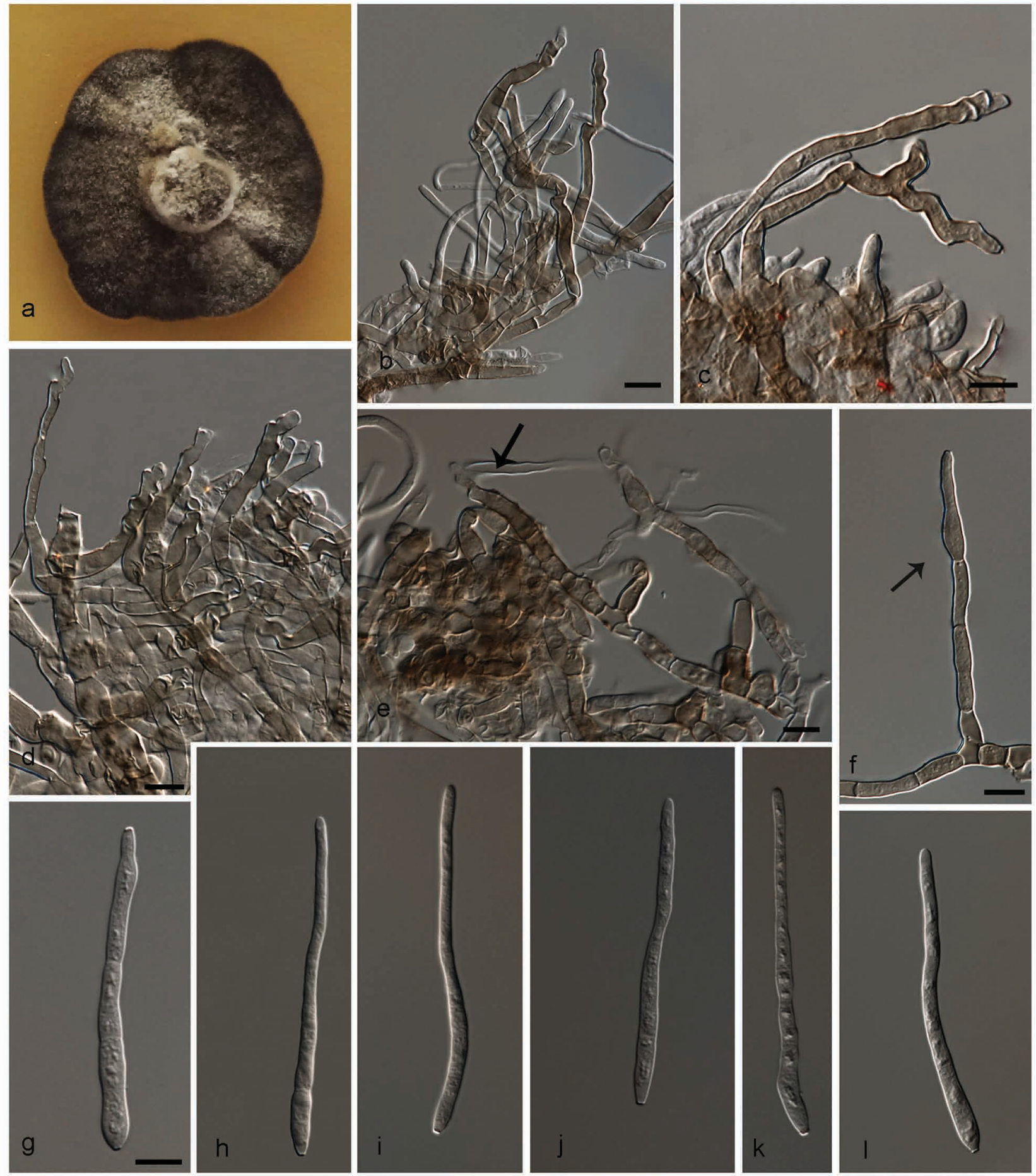

FIGURE 4. Neocercospora ammicola (CBS 136450) (in vitro). a. Colony on MEA. b-d. Conidiophores and conidiogenous cells. e. Terminal conidiophore on hypha. f. Conidiophore reduced to a conidiogenous cell. $\mathrm{g}-1$. Solitary and catenate conidia. Scale bars $=10$ $\mu \mathrm{m}$. 


\section{Discussion}

Since the application of molecular techniques to delineate genera of cercosporoid fungi, several genera, e.g. Pseudocercospora (Frank et al. 2010, Crous et al. 2013a), Stenella (Arzanlou et al. 2007) and Passalora (Braun et al. 2013, Hyde et al. 2013) have been revealed as being polyphyletic within the Mycosphaerellaceae. For many years the genus Cercospora has been treated as a general concept to accommodate a wide range of cercosporoid hyphomycetes that have pigmented conidiophores with conspicuously thickened and darkened conidiogenous loci (scars) and hyaline conidia formed singly with thickened and darkened conidial hila (Crous \& Braun 2003). By using this concept combined with a multi-locus molecular phylogenetic approach, the genus Cercospora was assumed to be monophyletic (Groenewald et al. 2013, Bakhshi et al. 2015). However a comprehensive phylogenetic examination of all known Cercospora species is required to confirm this assumption.

In the present study, we introduce the novel genus Neocercospora to accommodate the isolates occurring on Bishop's flower, which are cercospora-like in morphology, but cluster apart from Cercospora s.str. Based on the LSU phylogeny generated here (Fig. 1), Neocercospora resides in the Mycosphaerellaceae, with close neighbours being Phloeospora, Ramulispora and Pseudocercosporella capsellae (Fig. 1). In the combined gene tree, Neocercospora is a sister taxon to Pseudocercosporella capsellae, and clearly distinct from Cercospora, forming a well-supported clade with high Bayesian posterior probability (Fig. 2). Morphologically Neocercospora appears cercospora-like in morphology, but has conidiophores that are reduced to conidiogenous cells, and conidia that can occur in chains. Although both characteristics have been recorded among species of Cercospora s. str., further collections of additional species would have to reveal if it is the combination of these two features that in fact separates Neocercospora from Cercospora. In any case, non-congeneric, phylogenetically differentiated species should in future not be assigned to Cercospora s. str. to avoid further polyphyly.

In this study, as in numerous other recent studies (Crous et al. 2012, 2013a, 2013b, Hyde et al. 2013, Quaedvlieg et al. 2014), the limits of sole morphology-based classification for genera as well as species within the Mycosphaerellaceae were confirmed. There are several genera that are readily distinguishable based on even a single locus, but are visually impossible to identify based on solely morphological characteristics. For example, the genus Phaeocercospora is morphologically similar to and indistinguishable from Pseudocercospora species with consistently percurrently proliferating conidiogenous cells, but phylogenetically it is distinct (Crous et al. 2012). Microcyclosporella (Frank et al. 2010) is another genus that was introduced on the basis of phylogenetic data, showing that it clusters within the Mycosphaerellaceae. However, it is morphologically close to, and easily confused with, species of Microcyclospora (Frank et al. 2010) in Teratosphaeriaceae and Pseudocercosporella in Mycosphaerellaceae (Frank et al. 2010). The phylogenetic placement of such genera demonstrates that previous generic concepts and the sole reliance on particular morphological features are not always congruent with molecular phylogenies.

Our results also show that a single species of Pseudocercosporella, namely P. oxalidis, resides in the Cercospora s. str. clade. Pseudocercosporella was established based on P. ipomoeae by Deighton (1973) to accommodate cercosporellalike asexual morphs of Mycosphaerella, having unthickened and inconspicuous conidial scars. Recent phylogenetic studies have indicated Pseudocercosporella as being polyphyletic and comprising a genetically heterogeneous assemblage of fungi (Crous et al. 2009a, 2013a, Frank et al. 2010). Furthermore, Frank et al. (2010) revealed fungi with a pseudocercosporella-like morphology to reside in at least five clades distinct from the type species $P$. bakeri (= P. ipomoeae, see Braun 1995). The genus Pseudocercosporella is therefore in need of taxonomic revision pending the recollection of additional species thus far not known from culture. Based on our multi-gene phylogenetic data, P. oxalidis must be placed in the genus Cercospora, even though it has unthickened conidial hila and conidiogenous scars. Presently we are of the opinion that such a decision is premature, and that more species of Pseudocercosporella still need to be recollected and cultured to resolve the genera involved in this complex.

\section{Acknowledgements}

This work was financially supported by the Laboratory of Evolutionary Phytopathology, CBS-KNAW Fungal Biodiversity Centre, the Research Deputy of the University of Tabriz and the Studienstiftung für mykologische Systematik und Ökologie. We thank Prof. Uwe Braun for his valuable comments on an earlier version of this manuscript. 


\section{References}

Agrios, G.N. (2005) Plant pathology, 5th edition. Academic Press, New York, 922 pp.

Amaradasa, B.S., Madrid, H., Groenewald, J.Z., Crous, P.W. \& Amundsen, K. (2014) Porocercospora seminalis gen. et comb. nov., the causal organism of buffalograss false smut. Mycologia 106: 77-85. http://dx.doi.org/10.3852/13-147

Arzanlou, M., Groenewald, J.Z., Gams, W., Braun, U., Shin, H.D. \& Crous, P.W. (2007) Phylogenetic and morphotaxonomic revision of Ramichloridium and allied genera. Studies in Mycology 58: 57-93. http://dx.doi.org/10.3114/sim.2007.58.03

Arzanlou, M., Groenewald, J.Z., Fullerton, R.A., Abeln, E.C.A., Carlier, J., Zapater, M.F., Buddenhagen, I.W., Viljoen, A. \& Crous, P.W. (2008) Multiple gene genealogies and phenotypic characters differentiate several novel species of Mycosphaerella and related anamorphs on banana. Persoonia 20: 19-37. http://dx.doi.org/10.3767/003158508X302212

Bakhshi, M., Arzanlou, M. \& Babai-Ahari, A. (2011) Uneven distribution of mating type alleles in Iranian populations of Cercospora beticola, the causal agent of Cercospora leaf spot disease of sugar beet. Phytopathologia Mediterranea 50: 101-109. http://dx.doi.org/10.14601/Phytopathol_Mediterr-9009

Bakhshi, M., Arzanlou, M., Babai-Ahari, A., Groenewald, J.Z. \& Crous, P.W. (2014) Multi-gene analysis of Pseudocercospora spp. from Iran. Phytotaxa 184: 245-264.

http://dx.doi.org/10.11646/phytotaxa.184.5.1

Bakhshi, M., Arzanlou, M., Babai-ahari, A., Groenewald, J.Z., Braun, U. \& Crous, P.W. (2015) Application of the consolidated species concept to Cercospora spp. from Iran. Persoonia 34: 65-86. http://dx.doi.org/10.3767/003158515X685698

Braun, U. (1995) A monograph of Cercosporella, Ramularia and allied genera (phytopathogenic hyphomycetes). Ihw-Verlag Eching, Germany, $333 \mathrm{pp}$.

Braun, U. \& Crous, P.W. (2005) Additions and corrections to names published in Cercospora and Passalora. Mycotaxon 92: 395-416.

Braun, U., Nakashima, C. \& Crous, P.W. (2013) Cercosporoid fungi (Mycosphaerellaceae) 1. species on other fungi, Pteridophyta and Gymnospermae. IMA Fungus 4: 265-345.

http://dx.doi.org/10.5598/imafungus.2013.04.02.12

Braun, U., Crous, P.W. \& Nakashima, C. (2014) Cercosporoid fungi (Mycosphaerellaceae) 2. species on monocots (Acoraceae to Xyridaceae, excluding Poaceae). IMA Fungus 5: 203-390. http://dx.doi.org/10.5598/imafungus.2014.05.02.04

Carbone, I. \& Kohn, L.M. (1999) A method for designing primer sets for speciation studies in filamentous ascomycetes. Mycologia 91: $553-556$. http://dx.doi.org/10.2307/3761358

Chupp, C. (1954) A monograph of the fungus genus Cercospora. Published by the author, Ithaca, New York, $667 \mathrm{pp}$

Crous, P.W. \& Braun, U. (2003) Mycosphaerella and its anamorphs: 1. Names published in Cercospora and Passalora. CBS Biodiversity Series 1. CBS-KNAW Fungal Biodiversity Institute, Utrecht, The Netherlands, 571 pp.

Crous, P.W., Aptroot, A., Kang, J.C., Braun, U. \& Wingfield, M.J. (2000) The genus Mycosphaerella and its anamorphs. Studies in Mycology 45: 107-121.

Crous, P.W., Gams, W., Stalpers, J.A., Robert, V. \& Stegehuis, G. (2004a) MycoBank: an online initiative to launch mycology into the 21 st century. Studies in Mycology 50: 19-22.

Crous, P.W., Groenewald, J.Z., Pongpanich, K., Himaman, W., Arzanlou, M. \& Wingfield, M.J. (2004b) Cryptic speciation and host specificity among Mycosphaerella spp. occurring on Australian Acacia species grown as exotics in the tropics. Studies in Mycology 50: 457-469.

Crous, P.W., Groenewald, J.Z., Groenewald, M., Caldwell, P., Braun, U. \& Harrington, T.C. (2006) Species of Cercospora associated with grey leaf spot of maize. Studies in Mycology 55: 189-197.

Crous, P.W., Braun, U. \& Groenewald, J.Z. (2007) Mycosphaerella is polyphyletic. Studies in Mycology 58: 1-32. http://dx.doi.org/10.3114/sim.2007.58.01

Crous, P.W., Schoch, C.L., Hyde, K.D., Wood, A.R., Gueidan, C., de Hoog, G.S. \& Groenewald, J.Z. (2009a) Phylogenetic lineages in the Capnodiales. Studies in Mycology 64: 17-47.

Crous, P.W., Summerell, B.A., Carnegie, A.J., Wingfield, M.J., Hunter, G.C., Burgess, T.I., Andjic, V., Barber, P.A. \& Groenewald, J.Z. (2009b) Unravelling Mycosphaerella: do you believe in genera? Persoonia 23: 99-118. http://dx.doi.org/10.3767/003158509X479487 
Crous, P.W., Summerell, B.A., Shivas, R.G., Burgess, T.I., Decock, C.A., Dreyer, L.L., Granke, L.L., Guest, D.I., Hardy, G.E.S.J., Hausbeck, M.K., Hüberli, D., Jung, T., Koukol, O., Lennox, C.L., Liew, E.C.Y., Lombard, L., McTaggart, A.R., Pryke, J.S., Roets, F., Saude, C., Shuttleworth, L.A., Stukely, M.J.C., Vánky, K., Webster, B.J., Windstam, S.T. \& Groenewald, J.Z. (2012) Fungal Planet description sheets: 107-127. Persoonia 28: 138-182. http://dx.doi.org/10.3767/003158512X652633

Crous, P.W., Braun, U., Hunter, G.C., Wingfield, M.J., Verkley, G.J.M., Shin, H.D., Nakashima, C. \& Groenewald, J.Z. (2013a) Phylogenetic lineages in Pseudocercospora. Studies in Mycology 75: 37-114. http://dx.doi.org/10.3114/sim0005

Crous, P.W., Wingfield, M.J., Guarro, J., Cheewangkoon, R., Van der Bank, M., Swart, W.J., Stchigel, A.M., Cano-Lira, J.F., Roux, J., Madrid, H., Damm, U., Wood, A.R., Shuttleworth, L.A., Hodges, C.S., Munster, M., de Jesús Yáñez-Morales, M., Zúñiga-Estrada, L., Cruywagen, E.M., de Hoog, G.S., Silvera, C., Najafzadeh, J., Davison, E.M., Davison, P.J.N., Barrett, M.D., Barrett, R.L., Manamgoda, D.S., Minnis, A.M., Kleczewski, N.M., Flory, S.L., Castlebury, L.A., Clay, K., Hyde, K.D., Maússe-Sitoe, S.N.D., Chen, S.F., Lechat, C., Hairaud, M., Lesage-Meessen, L., Pawłowska, J., Wilk, M., Śliwińska-Wyrzychowska, A., Mętrak, M., Wrzosek, M., Pavlic-Zupanc, D., Maleme, H.M., Slippers, B., Mac Cormack, W.P., Archuby, D.I., Grünwald, N.J., Tellería, M.T., Dueñas, M., Martín, M.P., Marincowitz, S., de Beer, Z.W., Perez, C.A., Gené, J., Marin-Felix, Y. \& Groenewald, J.Z. (2013b) Fungal Planet description sheets: 154-213. Persoonia 31: 188-296.

http://doi.org/10.3767/003158513X675925

de Hoog, G.S. \& Gerrits van den Ende, A.H.G. (1998) Molecular diagnostics of clinical strains of filamentous Basidiomycetes. Mycoses 41: 183-189.

http://doi.org/10.1111/j.1439-0507.1998.tb00321.x

Deighton, F.C. (1967) Studies on Cercospora and allied genera. II. Passalora, Cercosporidium, and some species of Fusicladium on Euphorbia. Mycological Papers 112: 1-80.

Deighton, F.C. (1973) Studies on Cercospora and allied genera. IV. Cercosporella Sacc., Pseudocercosporella gen. nov. and Pseudocercosporidium gen. nov. Mycological Papers 133: 1-62.

Deighton, F.C. (1976) Studies on Cercospora and allied genera. VI. Pseudocercospora Speg., Pantospora Cif. and Cercoseptoria Petr. Mycological Papers 140: 1-168.

Deighton, F.C. (1979) Studies on Cercospora and allied genera VII. New species and redispositions. Mycological Papers 144: 1-156.

Deighton, F.C. (1987) New species of Pseudocercospora and Mycovellosiella, and new combinations into Pseudocercospora and Phaeoramularia. Transactions of the British Mycological Society 88: 365-391.

Deighton, F.C. (1990) Observations on Phaeoisariopsis. Mycological Research 94: 1096-1102.

Drummond, A., Ashton, B., Buxton, S., Cheung, M., Cooper, A., Duran, C., Field, M., Heled, J., Kearse, M., Markowitz, S., Moir, R., Stones-Havas, S., Sturrock, S., Thierer, T. \& Wilson, A. (2012) Geneious v5.6. Available from: http://www.geneious.com (accessed 18 May 2015)

Ellis, M.B. (1971) Dematiaceous hyphomycetes. Commonwealth Mycological Institute, Kew, England, 608 pp.

Ellis, M.B. (1976) More dematiaceous hyphomycetes. Commonwealth Mycological Institute, Kew, England, 507 pp.

Frank, J., Crous, P.W., Groenewald, J.Z., Oertel, B., Hyde, K.D., Phengsintham, P. \& Schroers, H.J. (2010) Microcyclospora and Microcyclosporella: novel genera accommodating epiphytic fungi causing sooty blotch on apple. Persoonia 24: 93-105. http://dx.doi.org/10.3767/003158510X510560

Fries, E.M. (1849) Summa vegetabilium Scandinaviae. Sectio Posterior. Stockholm, A. Bonnier, solus operis redemtor.

Fuckel, K.W.G.L. (1863) Fungi Rhenani exsiccati, Fasc. I-IV. Hedwigia 2: 132-136.

Goodwin, S.B., Dunkle, L.D. \& Zismann, V.L. (2001) Phylogenetic analysis of Cercospora and Mycosphaerella based on the internal transcribed spacer region of ribosomal DNA. Phytopathology 91: 648-658. http://dx.doi.org/10.1094/PHYTO.2001.91.7.648

Groenewald, J.Z., Nakashima, C., Nishikawa, J., Shin, H.D., Park, J.H., Jama, A.N., Groenewald, M., Braun, U. \& Crous, P.W. (2013) Species concepts in Cercospora: spotting the weeds among the roses. Studies in Mycology 75: 115-170. http://dx.doi.org/10.3114/sim0012

Hyde, K.D., Jones, E.B.G., Liu, J.K., Ariyawansa, H., Boehm, E., Boonmee, S., Braun, U., Chomnunti, P., Crous, P.W., Dai, D.Q., Diederich, P., Dissanayake, A., Doilom, M., Doveri, F., Hongsanan, S., Jayawardena, R., Lawrey, J.D., Li, Y.M., Liu, Y.X., Lücking, I.C., Shearer, C.A., Suetrong, S., Tanaka, K., Thambugala, K.M., Wijayawardene, N.N., Wikee, S., Wu, H.X., Zhang, Y., Aguirre-Hudson, B., Alias, S.A., Aptroot, A., Bahkali, A.H., Bezerra, J.L., Bhat, D.J., Camporesi, E., Chukeatirote, E., Gueidan, C., Hawksworth, D.L., Hirayama, K., de Hoog, S., Kang, J.C., Knudsen, K., Li, W.J., Li, X.H., Liu, Z.Y., Mapook, A., McKenzie, E.H.C., Miller, A.N., Mortimer, P.E., Phillips, A.J.L., Raja, H.A., Scheuer, C., Schumm, F., Taylor, J.E., Tian, Q., Tibpromma, S., Wanasinghe, D.N., Wang, Y., Xu, J.C., Yacharoen, S., Yan, J.Y. \& Zhang, M. (2013) Families of Dothideomycetes. Fungal Diversity $63:$ 1-313. http://dx.doi.org/10.1007/s13225-013-0263-4 
Katoh, K. \& Standley, D.M. (2013) MAFFT multiple sequence alignment software version 7: improvements in performance and usability. Molecular Biology and Evolution 30: 772-780. http://dx.doi.org/10.1093/molbev/mst010

Maddison, W.P. \& Maddison, D.R. (2011) Mesquite: a modular system for evolutionary analysis. Version 2.75. Available from: http:// mesquiteproject.org (accessed 18 May 2015)

Möller, E., Bahnweg, G., Sandermann, H. \& Geiger, H. (1992) A simple and efficient protocol for isolation of high molecular weight DNA from filamentous fungi, fruit bodies, and infected plant tissues. Nucleic Acids Research 20: 6115-6116. http://dx.doi.org/10.1093/nar/20.22.6115

Nakashima, C., Araki, I. \& Kobayashi, T. (2011) Addition and re-examination of Japanese species belonging to the genus Cercospora and allied genera. X: newly recorded species from Japan (5). Mycoscience 52: 253-259. http://dx.doi.org/10.1007/s10267-010-0094-z

Nylander, J.A.A. (2004) MrModeltest v2.0. Program distributed by the author. Evolutionary Biology Centre, Uppsala University, Uppsala, Sweden.

O’Donnell, K., Kistler, H.C., Cigelnik, E. \& Ploetz, R.C. (1998) Multiple evolutionary origins of the fungus causing Panama disease of banana: concordant evidence from nuclear and mitochondrial gene genealogies. Proceedings of the National Academy of Sciences 95: 2044-2049.

Pretorius, M.C., Crous, P.W., Groenewald, J.Z. \& Braun, U. (2003) Phylogeny of some cercosporoid fungi from Citrus. Sydowia 55: 286-305.

Quaedvlieg, W., Binder, M., Groenewald, J.Z., Summerell, B.A., Carnegie, A.J., Burgess, T.I. \& Crous, P.W. (2014) Introducing the Consolidated Species Concept to resolve species in the Teratosphaeriaceae. Persoonia 33: 1-40. http://dx.doi.org/10.3767/003158514X681981

Rannala, B. \& Yang, Z. (1996) Probability distribution of molecular evolutionary trees: a new method of phylogenetic inference. Journal of Molecular Evolution 43: 304-311. http://dx.doi.org/10.1007/BF02338839

Rayner, R.W. (1970) A mycological colour chart. CMI and British Mycological Society, Kew, Surrey, England, 34 pp.

Rehner, S.A. \& Samuels, G.J. (1994) Taxonomy and phylogeny of Gliocladium analysed from nuclear large subunit ribosomal DNA sequences. Mycological Research 98: 625-634. http://dx.doi.org/10.1016/S0953-7562(09)80409-7

Ronquist, F., Teslenko, M., van der Mark, P., Ayres, D.L., Darling, A., Höhna, S., Larget, B., Liu, L., Suchard, M.A. \& Huelsenbeck, J.P. (2012) MrBayes 3.2: efficient Bayesian phylogenetic inference and model choice across a large model space. Systematic Biology 61: 539-542. http://dx.doi.org/10.1093/sysbio/sys029

Tamura, K., Stecher, G., Peterson, D., Filipski, A. \& Kumar, S. (2013) MEGA6: Molecular Evolutionary Genetics Analysis Version 6.0. Molecular Biology and Evolution 30: 2725-2729. http://dx.doi.org/10.1093/molbev/mst197

Vilgalys, R. \& Hester, M. (1990) Rapid genetic identification and mapping of enzymatically amplified ribosomal DNA from several Cryptococcus species. Journal of Bacteriology 172: 4238-4246.

White, T.J., Bruns, T. \& Taylor, J. (1990) Amplification and direct sequencing of fungal ribosomal RNA genes for phylogenetics. In: Innis, M.A., Gelfand, D.H., Sninsky, J.J. \& White, J.W. (Eds.) A guide to molecular methods and applications. Academic Press, New York: 315-322 pp. 